\title{
Population Trends of Some Insect Pests of Rice Crop on Light Trap and its Relation to Abiotic Factors in Punjab Pakistan
}

\author{
Ijaz Haider ${ }^{1 *}$, Muhammad Akhtar ${ }^{1}$, Ali Noman ${ }^{2}$ and Muhammad Qasim³ \\ ${ }^{1}$ Rice Research Institute, Kala Shah Kaku, Lahore 39020 \\ ${ }^{2}$ Department of Botany, Govt. College University, Faisalabad 38040 \\ ${ }^{3}$ College of Plant Protection, Fujian Agriculture and Forestry University, Fuzhou \\ 350002, P.R. China
}

\begin{abstract}
A B S T R A C T
A research trial was conducted at Rice Research Institute, Kala Shah Kaku, Punjab, Pakistan to study the population fluctuation of five species of rice pests namely white stem borer Scirpophaga innotata (Walker), yellow stem borer Scirpophaga incertulas (Walker), rice leaffolder, Cnaphalocrocis medinalis (Guenée) (Lepidoptera: Pyralidae), whitebacked planthopper Sogatella furcifera (Horvath) (Homoptera: Delphacidae), and pink stem borer Sesamia inferens (Walker) (Lepidoptera: Noctuidae) on light trap. The effect of some abiotic factors like temperature, relative humidity and rainfall on the adult population of these pests was also studied. The population of these pests was monitored on the light trap from March to November from 2000 to 2014 in rice wheat cropping system. Yellow stem borer (YB), white stem borer (WB) and pink stem borer (PB) first appeared on the light trap in March when average temperature was $18^{\circ} \mathrm{C}$. YB and WB had first peak population in mid-April at temperatures $30-33^{\circ} \mathrm{C}$ while second peak was observed in mid-September. Pink stem borer first peak population was observed in mid-March while second in mid-November. Rice leaffolder (RLF) started to appear in $3^{\text {rd }}$ week of August. Peak population of whitebacked planthopper (WBPH) was observed in mid-October. Rainfall was found to be significantly positively correlated with WB population in March $\left(0.821^{*}\right)$ and October $\left(0.884^{*}\right)$. The population of yellow stem borer significantly and positively correlated with maximum temperature $\left(0.773^{*}\right)$ and minimum temperature $\left(0.824^{*}\right)$ in March and April respectively while it was negatively correlated with relative humidity $(-0.832 *)$ in April. Pink stem borer showed positive and significant relationship with rainfall $\left(0.764^{*}\right)$ and relative humidity $\left(0.779^{*}\right)$ in August and September respectively but negatively correlated with maximum temperature $\left(-0.947^{* *}\right)$ in September. Rice leaffolder and whitebacked planthopper had positive and negative correlations with meteorological factors but they were non-significant.
\end{abstract}

Article Information
Received 22 August 2019
Revised 01 March 2020
Accepted 13 April 2020
Available online 27 March 2021
Authors' Contribution
IH conceived and conducted the
research and wrote the manuscript.
MA supervised the project. AN
and MQ reviewed and revised the
manuscript.
Key words
Population trends, Light trap, Rice
insect pests, Meteorological factors,
Correlation analysis

Article Information

Received 22 August 2019

Revised 01 March 2020

Authors' Contribution

rived and conducted the

MA supervised the project. AN

and MQ reviewed and revised the

Population trends, Light trap, Rice

Correlation analysis

\section{INTRODUCTION}

$\mathrm{R}$ ice (Oryza sativa L.) is a major food source of over half of the global population and its demand is increasing every day. According to an estimate, we will be in need of additional 166 million tons or rice to feed the increasing population by 2035 (Seck et al., 2012). Rice is a second largest food crop in Pakistan which is also an export commodity. Due to rice exports Pakistan earns US\$ 2 billion of foreign exchange annually. It contributes 3.0 percent in the value added chain in agriculture and contributes 0.6 percent in GDP (Anonymous, 2018-19).

Attack of insect pests is one of the major yield limiting factors in rice which can cause up to $20-30 \%$ yield losses every year (Salim et al., 2001). Rice crop is attacked by many insect pests among them stem borers like yellow stem

\footnotetext{
Corresponding author: ijazhdr@gmail.com 0030-9923/2021/0003-1015 \$ 9.00/0 Copyright 2021 Zoological Society of Pakistan
}

borer Scirpophaga incertulas (Walker), white rice stem borer Scirpophaga innotata (Walker) and pink stem borer Sesamia inferens (Walker) are very important. Yellow stem borer (YSB) Scirpophaga incertulas (Walker) is very injurious insect pests of rice crop (Alam et al., 1992; Bandong and Litsinger, 2005). It attacks rice plants from seedling till crop harvest which causes unproductive tillers (Khan et al., 2010). White rice stem borer Scirpophaga innotata (Walker) and yellow stem borer Scirpophaga incertulas (Walker) attack rice plants and make dead heart and white heads due to which heavy yield losses occurs to rice crop (Rashid et al., 2013). According to Inayatullah et al. (1989), rice stem borers, Tryporyza incertulas and Tryporyza innotata causes $25 \%$ and $17 \%$ damage to rice crop respectively in Punjab province. Another most important pest species in early season rice is leaffolder Cnaphalocrocis medinalis (Guenee) (Lepidoptera: Pyralidae) (Heong et al., 1994; Heong and Escalada, 1997). Rice leaffolder is a major pest of rice crop and it can cause $30-40 \%$ leaf damage and $20-30 \%$ yield loss to 
rice crop (Haider et al., 2014). A single leaffolder larva can consume about $25 \mathrm{~cm}^{2}$ of leaf area which constitute less than $40 \%$ of leaf area of indica rice (Heong, 1993).

Sucking insect pests, like whitebacked planthopper (WBPH) Sogatella furcifera (Horvath) and brown planthopper (BPH) Nilaparveta lugens (Stal), constitute nearly $35 \%$ of the insect pests of rice. Planthoppers suck the phloem sap of the rice plant and causes heavy yield losses to rice crop (Zhou et al., 2019). The WBPH feeds on phloem tissues and causes damage to the rice plant which is called as hopper burn. Hopper-burn hinders the growth of rice plant and decreases rice crop production (Sumikarsih et al., 2019). Sogatella furcifera is known to transmit the fijivirus, the southern rice black streaked dwarf virus (SRBSDV) (Zhou et al., 2008) and rice black streak dwarf virus -2 (RBSDV-2) (Zhang et al., 2008). Rice planthoppers are the most destructive agricultural insect pests which can damage an area of about 20 million ha annually (Hu et al., 2014; Cheng, 2015). Sogatella furcifera can cause yield loss to rice by one million tons annually (Cheng et al., 2003).

Insects are all poikilothermic and they have no precise mechanism to regulate their body temperature. Temperature acts on insects in two folded manner: (i) by acting directly on survival, development and (ii) indirectly through food, humidity, rainfall, wind and atmospheric pressure.

Abiotic factors such as temperature, relative humidity and rainfall, has great influence on the outbreak of the insect population (Heong et al., 2007; Siswanto et al., 2008). Biotic as well as abiotic factors are responsible for population dynamics of insect pests (Singh et al., 2009). Population dynamics of rice stem borers like any other species are liable to fluctuate according to the varying condition of its environment (Khaliq et al., 2014). In order to reliably forecast insect populations, it is important to study correlation of important mortality factors, both biotic and abiotic with population increase of insect pest. Due to global warming pests will over winter due to suitable temperature if the host plant is available and the mortality of pests like whitebacked planthopper brown planthopper and rice leaffolder will decrease in winter generations but it also accelerate the rate of development and thus increase the population of insect pests which will damage the crop in successive generations (Kiritani, 1999, 2007). As the global climate is changing continuously, there is a requirement for studying the insect pest response to low frequency (annual or longer period) climate variability. Climate change has a significant effect on the population of insect pests and the change in the pest status and population dynamics (Estay et al., 2009; Karuppaiah et al., 2012). Climate change contributes to more recent out breaks of insect pests like planthoppers on rice crop.
Keeping in view all these considerations, the present research work was conducted in Punjab, Pakistan to find out the population dynamics of some rice insect pests on light trap and influence of meteorological parameters on population buildup of these insect pests so that their active period may be ascertained. This will help in their forecast and also different control strategies will be adopted in order to suppress them in the field condition and to avoid the damage caused by them to the rice crop.

\section{MATERIALS AND METHODS}

The present studies were carried out to investigate the population buildup of different rice insect pests on light trap. Five species of rice insect pests namely white stem borer Scirpophaga innotata (Walker), Yellow stem borer Scirpophaga incertulas (Walker), Rice leaffolder, Cnaphalocrocis medinalis (Guenée) (Lepidoptera: Pyralidae), Pink stem borer Sesamia inferens (Walker) (Lepidoptera: Noctuidae) and whitebacked planthopper Sogatella furcifera (Horvath) (Homoptera: Delphacidae) were monitored on the light trap from March till November during the years 2000 to 2014. Light trap was installed in the experimental fields of Rice Research Institute, Kala Shah Kaku, Lahore, Pakistan situated $31^{\circ} 45 \mathrm{~N}$ and $74^{\circ} 14$ $\mathrm{E}$ in rice wheat cropping system. During the experimental years rice nursery was sown during $1^{\text {st }}$ week of June and transplanted in first week of July. All the recommended agronomic practices like seed rate, fertilizer application, irrigation etc. were adopted for the cultivation of rice crop. Different plant protection measures were taken during the research period like use of cartap hydrochloride, lambda cyhalothrin and cypermethrin for the control of rice stem borers and rice leaffolder. For the control of planthoppers Imidacloprid, fipronil and carbosulfan were used. Insecticides were applied according to the level of insect infestation. Single or double applications of insecticides were applied. After the harvesting of rice crop stubbles were removed so as to destroy any hibernating larvae. Rice nursery was cultivated after $20^{\text {th }}$ May so as to avoid the attacked of newly emerging rice borers from hibernation.

Light traps with certain modifications were incorporated according to essential requirements of fields and trapped insects were identified and counted. The trap (Jermy type) had four constituent parts i.e. collecting chamber, funnel shaped lid, light source and a lid from the top to protect from unexpected rain showers. Light trap was locally made according to the standard specifications. The light source was a $100 \mathrm{~W}$ normal electrical bulb, hanged $200 \mathrm{~cm}$ above the ground in the light trap. Potassium cyanide bottles were used for the killing and trapping the insects. The light traps were installed at four 
different places about 600 meter apart in the research area of the institute and were checked daily for insects. Killing jars were changed as required by hand and trapped insects were counted. Insect pest population of four traps was averaged. The light trap data from 2010 to 2014 was pooled and used in analysis.

\section{Statistical analysis}

The weather data record of temperature, relative humidity and rainfall from 2000 to 2014 was collected from the Pakistan Meteorological Department, Lahore, Pakistan. The data was then analyzed and subjected to correlation analysis for ascertaining the efficacy of environmental factors on light trap catches of the insect pests. SPSS statistical software was used for the analysis and spearman's correlation coefficient was calculated between environmental variables and number of insect pests. Graphical representation were made by using Microsoft Excel work sheet.

\section{RESULTS}

\section{Population dynamics of white stem borer}

First peak population of this pest was recorded in April and average 45 number of borers were trapped in the light trap in this month (Fig. 1). Second peak was observed in September and 43 borers were recorded in light trap in this month. Correlation matrix revealed that rainfall showed significant $(\mathrm{P}<0.05)$ positive correlation $(0.821 *)$ with population buildup of WB in March (Table I). Maximum temperature recorded in March was $28^{\circ} \mathrm{C}$ (Fig. 3). In September it was significant $(\mathrm{P}<0.01)$ but $(-\mathrm{ve})$ correlated $(-0.924 * *)$ with rainfall. In October WB population was significantly $(\mathrm{P}<0.05)$ and positively correlated $\left(0.884^{*}\right)$ with rainfall. Max temperature was negatively correlated with WB population in June and July but it is non-significant. Minimum temperature had positive and non-significant correlation with WB in August. Relative humidity also had positive and non-significant association with WB population in July and October while negative and non-significant correlation was observed in April, August and September.

\section{Population dynamics of yellow stem borer}

First peak activity of yellow stem borer (YB) was recorded in April and 22 number of YB trapped in the light trap in this month. Second peak observed in September with 16 number of borers trapped in the light trap (Fig. 1). Correlation matrix showed that maximum temperature had significant $(\mathrm{P}<0.05)$ and positive correlation with population buildup of YB in March $\left(0.773^{*}\right)$. Maximum temperature recorded in March was $28^{\circ} \mathrm{C}$ (Fig. 3). Minimum temperature depict significant and positive $(\mathrm{P}<0.05)$ correlation with $\mathrm{YB}$ population in March
$(0.772 *)$, April $\left(0.824^{*}\right)$ and August $\left(0.792^{*}\right)$ (Table II). Minimum temperature recorded $16^{\circ} \mathrm{C}, 22^{\circ} \mathrm{C}$ and $27^{\circ} \mathrm{C}$ in March, April and August respectively (Fig. 3). Relative humidity had significant $(\mathrm{P}<0.01)$ negative correlation with YB $\left(-0.832^{*}\right)$ in April. Relative humidity recorded $39 \%$ in April.

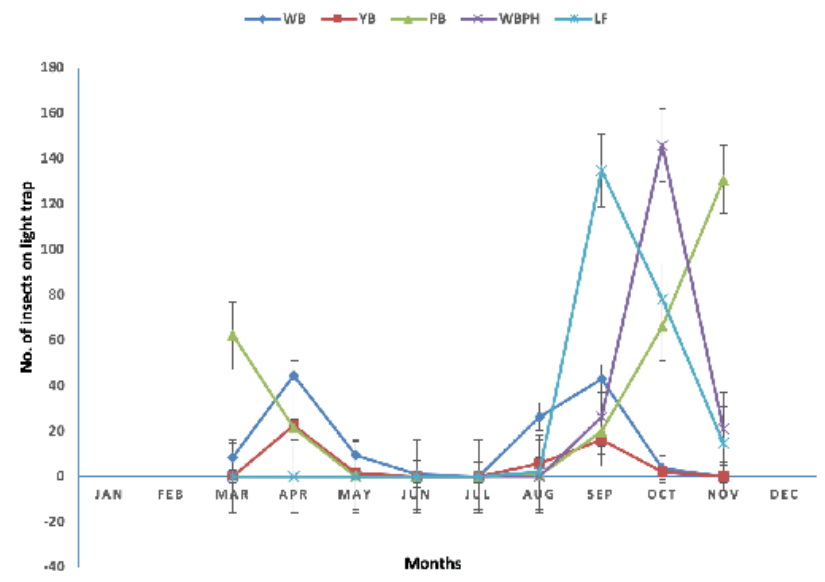

Fig. 1. Population fluctuation of different insect pests of rice crop on light trap at Rice Research Institute Kala Shah Kaku, Pakistan. WB (White stem borer) YB (Yellow stem borer) PB (Pink stem borer) WBPH (Whitebacked planthopper) LF (Leaffolder).

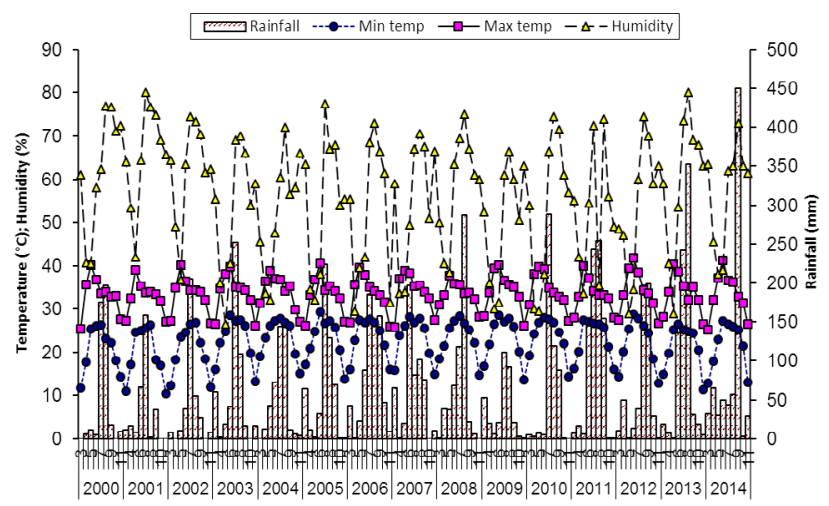

Fig. 2. Year wise trend of meteorological variables from 2000 to 2014 at Rice Research Institute Kala Shah Kaku. Pakistan.

\section{Population dynamics of pink stem borer}

First peak activity of this moth was recorded in midMarch (62 moths) and then again it started reappearing in August with max activity recorded in mid-November (131 moths) (Fig. 1). Correlation matrix revealed that rainfall had significant and positive $(\mathrm{P}<0.05)$ relationship with population of PB in September (0.803*) (Fig. 3). Maximum temperature was significantly and negatively correlated $(\mathrm{P}<0.01)$ with the population of this moth in 
Table I. Correlation matrix for white stem borer Scirpophaga innotata (Walker) with meteorological variables.

\begin{tabular}{lllllll}
\hline Month & Rainfall $(\mathbf{m m})$ & Max temp $\left({ }^{\circ} \mathbf{C}\right)$ & Min temp $\left({ }^{\circ} \mathbf{C}\right)$ & RH $(8 a m)$ & RH $(\mathbf{5 p m})$ & RH \\
\hline Mar & $0.821^{*}$ & 0.138 & 0.286 & -0.332 & -0.211 & -0.285 \\
Apr & -0.283 & 0.222 & 0.521 & -0.575 & -0.496 & -0.547 \\
May & -0.363 & 0.255 & 0.639 & -0.101 & -0.058 & -0.078 \\
Jun & 0.529 & -0.670 & -0.175 & 0.443 & 0.405 & 0.427 \\
Jul & 0.368 & -0.561 & -0.044 & 0.436 & 0.617 & 0.544 \\
Aug & -0.266 & 0.366 & 0.706 & -0.473 & -0.336 & -0.520 \\
Sep & $-0.924^{* *}$ & 0.675 & 0.290 & -0.695 & -0.506 & -0.592 \\
Oct & $0.884^{*}$ & -0.433 & -0.572 & 0.525 & 0.545 & - \\
Nov & - & - & - & - & - & - \\
\hline
\end{tabular}

Table II. Correlation matrix for yellow stem borer Scirpophaga incertulas (Walker) with meteorological variables.

\begin{tabular}{|c|c|c|c|c|c|c|}
\hline Month & Rainfall (mm) & Max temp $\left({ }^{\circ} \mathrm{C}\right)$ & Min temp $\left({ }^{\circ} \mathrm{C}\right)$ & RH (8am) & RH (5pm) & RH \\
\hline Mar & -0.418 & $0.773 *$ & $0.772 *$ & 0.014 & -0.286 & -0.133 \\
\hline Apr & -0.439 & 0.656 & $0.824 *$ & $-0.849^{*}$ & -0.791 & $-0.832^{*}$ \\
\hline May & -0.385 & 0.324 & 0.756 & -0.146 & -0.094 & -0.119 \\
\hline Jun & - & - & - & - & - & - \\
\hline Jul & - & - & - & - & - & - \\
\hline Aug & -0.420 & 0.408 & $0.792 *$ & -0.469 & -0.365 & 0.007 \\
\hline Sep & -0.281 & -0.183 & 0.698 & -0.007 & 0.080 & 0.043 \\
\hline Oct & 0.151 & 0.182 & -0.039 & 0.222 & 0.072 & 0.130 \\
\hline Nov & - & - & - & - & - & - \\
\hline
\end{tabular}

Table III. Correlation matrix for pink stem borer Sesamia inferens (Walker) with meteorological variables.

\begin{tabular}{lllllll}
\hline Month & Rainfall $(\mathbf{m m})$ & Max temp $\left({ }^{\circ} \mathbf{C}\right)$ & Min temp $\left({ }^{\circ} \mathbf{C}\right)$ & RH $(8 a m)$ & RH $(5 \mathbf{p m})$ & RH \\
\hline Mar & -0.724 & 0.159 & 0.235 & 0.275 & -0.023 & 0.139 \\
Apr & 0.768 & -0.730 & -0.720 & 0.736 & 0.581 & 0.677 \\
May & $0.964^{* *}$ & $-0.938^{* *}$ & $-0.839^{*}$ & $0.878^{*}$ & $0.88^{*}$ & $0.883^{*}$ \\
Jun & - & - & - & - & - & - \\
Jul & - & - & - & - & - & - \\
Aug & $0.764^{*}$ & -0.707 & -0.752 & 0.617 & 0.57 & 0.439 \\
Sep & $0.803^{*}$ & $-0.947^{* *}$ & -0.195 & $0.779^{*}$ & 0.653 & 0.713 \\
Oct & -0.094 & 0.233 & -0.335 & $-0.764^{*}$ & -0.666 & -0.707 \\
Nov & -0.301 & -0.033 & 0.459 & -0.328 & 0.493 & -0.213 \\
\hline
\end{tabular}

September $\left(-0.947^{* *}\right)$. Maximum temperature recorded $34^{\circ} \mathrm{C}$ in September (Fig. 3). Relative humidity was significantly and positively correlated with the population of this moth in September $\left(0.779^{*}\right)$ and it had negative but significant correlation with PB population in October
$(-0.764 *)$. Relative humidity was recorded $69 \%$ and $60 \%$ in September and October, respectively (Fig. 3).

Population dynamics of whitebacked planthopper The population of this pest started to appear in the 
month of August and its peak activity was observed in mid-October (146 Hoppers) (Fig. 1). Environmental factors have affected the population of WBPH but they were non-significant. Correlation analysis revealed that rainfall had positive correlation (0.602) with WBPH population in October (Table IV). Maximum temperature had positive correlation (0.625) with WBPH in November. Minimum temperature was negatively correlated with WBPH population in September $(-0.510)$, however it had positive and non-significant correlation (0.545) with WBPH population in November. Relative humidity had negative correlation with WBPH population in November $(-0.716)$.

Table IV. Correlation matrix for whitebacked planthopper Sogatella furcifera (Horvath) with meteorological variables.

\begin{tabular}{lllllll}
\hline Month & $\begin{array}{l}\text { Rainfall } \\
(\mathbf{m m})\end{array}$ & $\begin{array}{l}\text { Max temp Min temp } \\
\left({ }^{\circ} \mathbf{C}\right)\end{array}$ & $\begin{array}{l}\text { RH } \\
\left({ }^{\circ} \mathbf{C}\right)\end{array}$ & $\begin{array}{l}\text { RH } \\
(\mathbf{8 a m})\end{array}$ & $\begin{array}{l}\text { RH } \\
(5 \mathbf{p m})\end{array}$ \\
\hline Mar & - & - & - & - & - & - \\
Apr & - & - & - & - & - & - \\
May & - & - & - & - & - & - \\
Jun & - & - & - & - & - & - \\
Jul & - & - & - & - & - & - \\
Aug & - & - & - & - & - & - \\
Sep & 0.079 & -0.236 & -0.510 & 0.057 & 0.110 & 0.088 \\
Oct & 0.602 & -0.071 & -0.443 & 0.348 & 0.244 & 0.285 \\
Nov & -0.367 & 0.625 & 0.545 & -0.716 & 0.549 & -0.601 \\
\hline
\end{tabular}

Population dynamics of rice leaffolder

Rice leaffolder adults started to appear on light trap in mid-August with peak population in mid-September (135 Moths) which gradually decreases in mid-November (Fig. 1). The meteorological variables were found to have non-significant effect on population buildup of rice leaffolder. Rain fall was negatively correlated $(\mathrm{P}>0.05)$ with leaffolder population in September $(-0.591)$ but this correlation was positive in October (0.707) (Table V). Maximum temperature was negatively correlated with LF population $(\mathrm{P}>0.05)$ in November $(-0.519)$. Minimum temperature was negatively correlated $(\mathrm{P}>0.05)$ with LF population in September (-0.617) and October (-0.739). Relative humidity had negative association with LF population in August (-0.633).

\section{DISCUSSION}

It is well known that weather particularly temperature greatly influences the abundance, rate of development and number of generations of an insect species in the environment. The interaction between the different environmental factors (biological and physical) biotic, abiotic environmental factors and host plant is very complex. In this research experiment we tried to dig out some interesting links between insect pest fluctuation and abiotic factors like temperature, humidity and rainfall from a data base from 2000 to 2014. Laszlo et al. (2012) studied the efficacy of light traps influenced by environmental factors and they found that the efficacy of light traps increases with the increase in temperature. Influence of weather parameters on abundance of insect pests on light trap is discussed by many authors (McGeachie, 1989; Holloway et al., 2001). Ramamurthy et al. (2010) concluded that average temperature showed significant relationship with lepidopterans, hemipterans and coleopterans when all types of insect traps considered together.

Table V. Correlation matrix for leaf folder Cnaphalocrocis medinalis (Guenée) with meteorological variables.

\begin{tabular}{lllllll}
\hline $\begin{array}{l}\text { Month Rainfall Max temp Min temp RH } \\
(\mathbf{m m})\end{array}$ & $\left({ }^{\circ} \mathbf{C}\right)$ & $\left({ }^{\circ} \mathbf{C}\right)$ & $\begin{array}{l}\text { RH } \\
(8 a m)\end{array}$ & $\begin{array}{l}\text { RH } \\
\text { (5pm) }\end{array}$ \\
\hline Mar & - & - & - & - & - & - \\
Apr & - & - & - & - & - & - \\
May & - & - & - & - & - & - \\
Jun & - & - & - & - & - & - \\
Jul & - & - & - & - & - & - \\
Aug & 0.289 & -0.288 & 0.081 & 0.364 & 0.432 & -0.633 \\
Sep & -0.591 & 0.377 & -0.617 & -0.098 & -0.058 & -0.076 \\
Oct & 0.707 & -0.376 & -0.739 & -0.167 & -0.072 & -0.109 \\
Nov & -0.205 & -0.519 & 0.031 & 0.239 & 0.255 & 0.313 \\
\hline
\end{tabular}

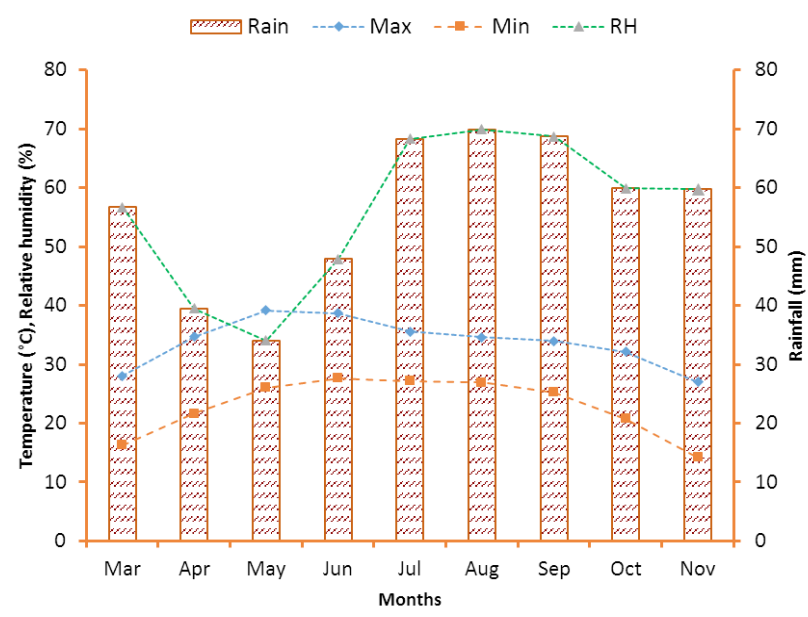

Fig. 3. Mean monthly meteorological variables from March to November during the period 2000 to 2014 at Rice Research Institute Kala Shah Kaku. Pakistan. 
It is evident from the data that population of white stem borer and yellow stem borer have shown positive and significant correlation with weather parameters. Both the insects started to appear in March on light trap when temperature is around $19^{\circ} \mathrm{C}$ (Fig. 3). In mid-April their peak activity was recorded at the temperature of $28-31^{\circ} \mathrm{C}$. After that as temperature raised in May, population of both the insects became negligible when average temperature reached $32^{\circ} \mathrm{C}$. Second peak observed in August and September at temperature $31^{\circ} \mathrm{C}$. Similar observations were recorded by Santiago and Sebastian (1999) who studied the light trap catches of yellow stem borer from 1997 to 1999. They observed two population peaks, one from last week of March to third week of May and second from September to October. Pathak and Zeyaur (1994) observed maximum number of insect activity of YB and WB above $29^{\circ} \mathrm{C}$ (Fig. 3). Pink stem borer appears on light trap in March after hibernation and it feeds on early sown rice nursery. It also shifts on wheat crop because of its polyphagous nature. Its second severe attack observed at grain filling stage of rice crop in October and November at temperatures $26^{\circ} \mathrm{C}$ and $21^{\circ} \mathrm{C}$ respectively. PB has shown significant correlations with maximum temperature, rainfall and relative humidity in September and October. Rice leaffolder appears on rice crop in third week of August when rice leaves are maturing and remains active till end of November. WBPH started to appear in significant numbers on light trap in September and its peak activity was recorded in mid-October when rice crop is at grain filling stage. According to Prasannakumar et al. (2015), yellow stem borer population is significantly and negatively correlated with maximum and minimum temperature in October and November respectively while it was negatively correlated with rain fall in October and with relative humidity in November. These findings are somewhat different as we investigated that YB population is positively correlated with maximum and minimum temperatures in March, April and August while it was significantly $(-\mathrm{ve})$ correlated with rain fall in April. These differences may be due to the difference in the geographical and environmental conditions of both regions. Results of the current investigation are supported by the findings of Ashrith et al. (2017) who studied the influence of meteorological variables on the occurrence of major insect pests of rice crop. They revealed that high population of YB was observed in $2^{\text {nd }}$ fortnight of April at $37^{\circ} \mathrm{C}$ temperature and $52 \% \mathrm{RH}$. Maximum temperature exerts positive affect on the population of YB. Results of our experiment are not corroborated with Chakraborty and Nandi (2011) who stated that minimum temperature was negatively correlated while relative humidity has shown positive correlation with yellow stem borer population as we observed minimum temperature had significant and positive correlation while relative humidity was negatively correlated with population buildup of YB population. According to Prasad et al. (2010) WBPH population had shown negative and significant correlation with maximum temperature, positive and significant correlation with minimum temperature and (+ve) significant association with morning and evening relative humidity. These findings partially supports our results as we recorded positive and non-significant correlations between rainfall, maximum, minimum temperature and WBPH population. These differences in results may be due the geography and environment of the area as these observations were made in rain fed areas.

The population of insects have shown correlation with rainstorms (Tucker, 1994). Many synoptic scale studies have shown association of insect catches and rainfall (Watnabe et al., 1991). Guowen et al. (1995) studied the Nilaparvata lugens and Sogatella furcifera, frequent outbreak in wuling rice-growing area in south China and found that the weather during the period of the planthopper immigration (from April to September) is usually characteristic by maintained stationary front cyclone and continuing cloudy and rainy days which favors landing of immigrated planthoppers. Population dynamics of brown planthopper (BPH) and whitebacked planthopper (WBPH) was investigated in Myanmar for two years by Win et al. (2011). The study revealed that 64 to 74 days after transplanting (in mid-September) BPH population was high which is positively correlated with high rainfall, temperature and humidity. In this study we also observed correlations between rainfall, relative humidity, temperature and WBPH population. Bhatnager and Saxena (1999) reported that minimum temperature is very important in the population buildup of rice gundhi bug and green leafhopper besides rainfall and evening relative humidity. Pandey et al. (2001), revealed that relative humidity is very important in the population buildup of yellow stem borer. Similar results were found by Chakraborty and Deb (2011) who stated that peak population of RLF was recorded in 33 and 34 SMW (standard meteorological weeks). Minimum temperature had significant and positive correlation with population of RLF. In current investigation we also noted peak activity of RLF in August ( $3^{\text {rd }}$ week). The correlation study somewhat differ with them as they found negative and insignificant correlation with rainfall but we recorded some positive but non-significant correlations values. Also, minimum temperature found to have non-significant and negative correlation with population buildup of RLF. Results of our experiment are supported by the work of Ram et al. (2014) who stated that population of RLF increased in the end of August. They also showed that all the meteorological 
variables have negative correlation with population buildup of RLF. Similar results were also observed in our experiment.

\section{CONCLUSION}

It is therefore concluded from the above discussion that abiotic factors like temperature, humidity and rainfall have very significant effect on the population fluctuation of rice insect pests. This information is very much helpful in the forecast of these insect pest which is ultimately very important in their effective management. Based on this information it is clear that most of the moth population appears in the April and early May. So, rice farmers are advised not to sow their rice nursery before mid-May so as to avoid this pest attack. Also avoid late sowing and transplanting of rice crop as it will be more vulnerable to borers, leaffolder and planthoppers. Insect population on the light trap can be used as economic threshold level (ETL) so that we can better plan our plant protection measures against these pests. However, while keeping in view these findings certain other biotic factors along with abiotic factors may also be responsible for population dynamics of insect pests in an environment like abundance of natural enemies, migration, biology, alternate host plants. The study of these factors can become good topics for further investigations on population dynamics of rice insect pests.

\section{Statement of conflict of interest}

The authors have declared no conflict of interest.

\section{REFERENCES}

Alam, N., Sing, R., Yadav, R.P. and Goel, S.C., 1992. Population dynamics of borer complex in deep water rice. Bioecology and control of insect pests. In: Proceedings of the National Symposium on Growth Development and Control Technology of Insect Pests, Muzaffarnagar, India. pp. 95-99.

Anonymous, 2018-19. Economic survey of Pakistan. Finance division. Economic advisory wing, Islamabad.

Ashrith, K.N., Sreenivas, A.G., Guruprasad, G.S., Patil, N.B., Hanchinal, S.G. and Chavan, I., 2017. Influence of weather parameters on the occurrence of major insect-pests in conventional rice ecosystem. Oryza, 54: 324-329. https://doi. org/10.5958/2249-5266.2017.00044.3

Bandong, J.P. and Litsinger, J.A., 2005. Rice crop stage susceptibility to the rice yellow stem borer Scirpophaga incertulas (Walker) (Lepidoptera:
Pyralidae). Int. J. Pest Manage., 51: 37-43. https:// doi.org/10.1080/09670870400028276

Bhatnager, A. and Saxena, R.R., 1999. Environmental correlates of population buildup of rice insect pests through light trap catches. Oryza, 36: 241-245.

Chakraborty, K. and Deb, D.C., 2011. Incidence of adult leaffolder, Cnaphalocrocis medinalis (Lepidoptera: Pyralidae) on paddy crop in the agro climatic conditions of the northern parts of West Bengal, India. World J. agric. Sci., 7: 738-742.

Chakraborty, K. and Nandi, P.S., 2011. Incidence of paddy yellow stem borer (scirpophaga incertulas (Walker) in relation to the agro climatic region of Hemtabad, Uttar Dinajpur, West Bengal, India. Res. Analys. Evalu., 2: 48-49.

Cheng, J.A., 2015. Rice planthoppers in the past half century in China. In: Rice planthoppers, ecology, management, socio economics and policy (eds. K.L. Heong, J.A. Cheng and M.M. Escalada). Zhejiang University and Springer, Hangzhou. pp. 1-32. https://doi.org/10.1007/978-94-017-9535$7 \_1$

Cheng, X.N., Wu, J.C. and Ma, F., 2003. Research and prevention of the brown planthopper. Chinese Agric. Press Beijing China. pp. 52-55.

Estay, S.A., Lima, M. and Labra, F.A., 2009. Predicting insect pest status under climate change scenarios: combining experimental data and population dynamics modelling. J. appl. Ent., 133: 491-499. https://doi.org/10.1111/j.1439-0418.2008.01380.x

Guowen, H., Min, Z., Jian, T., Qunwei, P., Zejun, R. and Keming, Y., 1995. Potential causal factors for the outbreak of the rice planthoppers in wuling mountainous area. S. W. China J. agric. Sci., 17: 123-127.

Haider, I., Akhter, M. and Sabir, A.M., 2014. Evaluation of different insecticides against rice leaffolder Cnaphalocrocis medinalis (Guenee) under field conditions. Pakistan J. Zool., 46: 1458-1461.

Heong, K.L., Manza, A., Catindig, J., Villareal, S. and Jacobsen, T., 2007. Changes in pesticide use and arthropod biodiversity in the IRRI research farm. Outlooks Pest Manage., 18: 229-233. https://doi. org/10.1564/18oct11

Heong, K.L., 1993. Rice leaffolders: Are they serious pests? Research on rice leaffolder management in China. Proceedings of international workshop on economic threshold of rice leaffolders in China, 4-6 March 1992, Beijing, China. China National Rice Research Institute. pp. 8-11.

Heong, K.L., Escalada, M.M. and Mai, V., 1994. An analysis of insecticide use in rice. Case- 
studies in the Philippines and Vietnam. Int. J. Pest Manage., 40: 173-178. https://doi. org/10.1080/09670879409371878

Heong, K.L. and Escalada, M.M., 1997. A comparative analysis of pest management practices of rice farmers in Asia. In: Pest management of rice farmers in Asia (eds. K.L. Heong and M.M. Escalada). Int. Rice Res. Inst., Philippines, pp. 227-242.

Holloway, J.D., Kibby, G. and Peggie, D., 2001. The families of malesian moths and butterflies. Fauna Malesiana Handbook 3. Brill (Leiden, Boston, Koln).

Hu, G., Lu, F., Zhai, B.P., Lu, M.H., Liu, W.C., Zhu, F., Wu, X.W., Chen, G.H. and Zhang, X.X., 2014. Outbreaks of the brown planthopper Nilaparvata lugens (Stål) in the Yangtze River delta: Immigration or local reproduction. PLoS One, 9: e88973. https:// doi.org/10.1371/journal.pone.0088973

Intachat, J., and Woiwod, I.P., 1999. Trap design for monitoring moth biodiversity in tropical rainforests. Bull. entomol. Res., 89: 153-163. https://doi. org/10.1017/S0007485399000243

Inayatullah, C.E., 1989. Incidence of rice stem-borers (SB) in the Punjab. Int. Rice Res. Inst., 14: 38.

IBM SPSS Statistics for Windows. 2016. Version 24.0. Armonk, NY: IBM Corp.

Karuppaiah, V. and Sujayanad, G.K., 2012. Impact of climate change on population dynamics of insect pests. World J. agric. Sci., 8: 240-246.

Kiritani, K., 1999. Shift of IPM strategy for rice under global warming in temperate areas. In: Integrated pest management in rice based ecosystem (eds. R. Zhang, D. Gu, W. Zhang, C. Zhou and Y. Pang). Zhongshan University Press, Guangzhou, P.R. China. pp. 235-244.

Kiritani, K., 2007. The impact of global warming and land use change on the pest status of rice and fruit bugs (Heteroptera) in Japan. Glob. Change Biol., 13:1586-1595. https://doi.org/10.1111/j.13652486.2007.01397.x

Khaliq, A., Javed, M., Sohail, M. and Sagheer, M., 2014. Environmental effects on insects and their population dynamics. J. Ent. Zool. Stud., 2: 1-7.

Khan, S.M. Murtaza, G. and Mir, H., 2010. Screening of six rice varieties against yellow stem borer, Scirpophaga incertulus (Walker). Sarhad J. Agric. 26: 591-594.

Laszlo, N., Janos, P. and Marta, L., 2012. Efficiency of light-traps influenced by environmental factors. Intl. J. Sci. Nat. 3: 521-525.

McGeachie, W.J., 1989. The effect of moonlight illuminance, temperature and wind speed on light trap catch of moths. Bull. entomol. Res., 79: $185-$ 192. https://doi.org/10.1017/S0007485300018162

Pandey, V, Sharma, M.K. and Singh, R.S., 2001. Effect of weather parameters on light trap catches of yellow stem borer, Scirpophaga incertulus Walker. Shashpa, 8: 55-57.

Pathak, M.D. and Zeyaur, R.K., 1994. Insect pests of rice. Int. Rice Res. Inst. Philippines, pp. 6.

Prasannakumar, N.R., Chander, S. and Kumar L.V., 2015. Development of weather based rice yellow stem borer prediction model for the Cauvery command rice areas, Karnataka, India. Cogent Fd. Agric., 1: 995281. https://doi.org/10.1080/23311932.2014.99 5281

Prasad, R., Prabhu S.T. and Balikai, R.A., 2010. Incidence of whitebacked planthopper on rice and its predators under rainfed ecosystems and their correlation with weather parameters. Res. J. agric. Sci., 1: 322-326

Ram, M., Sachan, S.K. and Singh G., 2014. Study on population buildup of rice leaffolder, Cnaphalocrocis medinalis (Guenee) in relation to weather factors. Int. J. Adv. Res., 2: 75-77.

Ramamurthy, V.V., Akhtar, M.S., Patankar, N.V., Menon, P., Kumar, R., Singh, S.K., Ayri, S., Parveen, S. and V. Mittal, V., 2010. Efficiency of different light sources in light traps in monitoring insect diversity. Munis entomol. Zool., 5: 109-114.

Rashid, M.M., Khattak, M.K., Momin, A., Amir, M., Bibi, R. and Latif, A., 2013. Performance of different rice cultivars and insecticides against Tryporyza incertulas (Walker) and Cnaphalocrocis medinalis (Guenee). Pak. J. agri. Sci., 50: 625-629.

Salim, M., Masud, S.A. and Ramzan, M., 2001. Integrated pest management of basmati rice. Rices of the world: Breeding, production and marketing, FAO, Rome, Italy.

Santiago, R.O. and Sebastian. L.S., 1999. Rice stem borers in Philippines. Int. Rice Res. Inst. Philippines, pp. 8.

Siswanto, R.M., Dzolkhifli, O. and Elna, K., 2008. Population fluctuation of Helopeltis antonii Signoret on cashew Anacarcium occidentalle L. in Java Indonesia. Pertanika J. tropic. agric. Sci., 31: 191196.

Singh, S.P., Sekhon, B.S., Brar, J.S., Dhaliwal, L.K. and Chahal, S.K., 2009. Effect of weather parameters and plant geometry on sucking pests dynamics in $\mathrm{Bt}$ and non Bt cotton. In $4^{\text {th }}$ National seminar on agrometeorology-needs approaches and linkages for rural development, Hisar, India. pp. 12-13.

Seck, P.A., Diagne, A., Mohanty, S. and Wopereis, M.C., 2012. Crops that feed the world 7: Rice. Fd. Security. 
4: 7-24. https://doi.org/10.1007/s12571-012-0168-1

Sumikarsih, E., Herlinda, S. and Pujiastuti, Y., 2019.

Conidial density and viability of Beauveria bassiana isolates from Java and Sumatra and their virulence against Nilaparvata lugens at different temperatures. Agrivita J. agri. Sci., 41: 335-335. https://doi. org/10.17503/agrivita.v41i2.2105

Tucker, M.R., 1994. Light-trap catches of African armyworm moths, Spodoptera exempta (Walker) (Lepidoptera: Noctuidae) in relation to rain and wind. Bull. entomol. Res., 73: 315-319. https://doi. org/10.1017/S0007485300008907

Watanabe, T., Sogawa, K., Hirai, Y., Tsurumachi, M., Fukamachi S. and Ogawa Y., 1991. Correlation between migratory flight of rice planthoppers and the low-level jet stream in Kyushu, South western Japan. Appl. Ent. Zool., 26: 215-222. https://doi. org/10.1303/aez.26.215

Win, S., Muhammad, R., Ahmad, Z.A.M. and Adam, N.A., 2011. Population fluctuations of brown planthopper Nilaparvata lugens Stal. and whitebacked planthopper Sogatella furcifera (Horvath) on rice. J. Ent., 8: 183-190. https://doi. org/10.3923/je.2011.183.190

Zhang, H.M., Yang, J., Chen, J.P. and Adams, M.J., 2008. A black-streaked dwarf disease on rice in China is caused by a noval Fijivirus. Arch. Virol., 153: 18931898. https://doi.org/10.1007/s00705-008-0209-4

Zhou, G.H., Wen, J.J., Cai, D.J., Li, P. Xum, D.L. and Zhang, S.G., 2008. Southern rice black-streaked dwarf virus: A new proposed Fijivirus species in the family Reoviridae. Chinese Sci. Bull., 53: 36773685. https://doi.org/10.1007/s11434-008-0467-2

Zhou, S., Chen, M., Zhang, Y. Gao, Q., Noman, A., Wang, Q., Li, H., Chen, L., Zhou, P., Lu, J. and Lou, Y., 2019. OsMKK3, a stress-responsive protein kinase, positively regulates rice resistance to Nilaparvata lugens via phytohormone dynamics. Int. J. mol. Sci., 20: 3023. https://doi.org/10.3390/ijms20123023 